\title{
Nursing care time in the Intensive Care Unit: evaluation of the parameters proposed in COFEN Resolution No 293/04
}

\author{
Fernanda Maria Togeiro Fugulin ${ }^{2}$ \\ Ana Cristina Rossetti ${ }^{3}$ \\ Carolina Martins Ricardo ${ }^{4}$ \\ João Francisco Possari ${ }^{5}$ \\ Maria Cristina Mello 5 \\ Raquel Rapone Gaidzinski ${ }^{6}$
}

This study aimed to evaluate the parameters established in COFEN Resolution 293/04 concerning nursing staff dimensioning in adult intensive care units (AICU). The research was conducted in six hospitals in São Paulo City. The daily quantitative average of professionals needed for patient care was calculated according to the parameters established by COFEN. The obtained results were compared with the existing number of daily staff members in these units. It was observed that the proportions recommended by COFEN for the nurse category are superior to those used in the hospitals studied, which represents a challenge for Brazilian nursing. Mean care time values were found appropriate and represent important standards for dimensioning the minimum number of professionals in AICU. This study contributed to the validation of the parameters indicated in Resolution 293/04 for nursing staff dimensioning in the AICU.

Descriptors: Personnel Management; Nursing Staff, Hospital; Workload.

\footnotetext{
${ }^{1}$ Paper extracted from Free Lectureship Thesis "Parâmetros oficiais para o dimensionamento de profissionais de enfermagem em institições hospitalares: análise da Resolução COFEN n²93/04", apresentada à Escola de Enfermagem, Universidade de São Paulo, Brazil. Supported by Fundação de Amparo à Pesquisa do Estado de São Paulo (FAPESP), process \# 2006/51010-2.

2 Free lecturer, Associate Professor, Escola de Enfermagem, Universidade de São Paulo, Brazil.

${ }^{3}$ MSc, Escola de Enfermagem, Universidade de São Paulo, Brazil.

${ }^{4}$ Master's student, Escola de Enfermagem, Universidade de São Paulo, Brazil.

${ }^{5}$ Doctoral student, Escola de Enfermagem, Universidade de São Paulo, Brazil.

${ }^{6} \mathrm{PhD}$, Full Professor, Escola de Enfermagem, Universidade de São Paulo, Brazil.
}

Corresponding Author:

Fernanda Maria Togeiro Fugulin

Universidade de São Paulo. Escola de Enfermagem

Av. Dr. Enéas de Carvalho Aguiar, 419

Bairro: Cerqueira César

CEP: 05403-000, São Paulo, SP, Brasil

E-mail: ffugulim@usp.br 


\section{Tempo de assistência de Enfermagem em Unidade de Terapia Intensiva: avaliação dos parâmetros propostos pela Resolução COFEN n²93/04}

O estudo teve por objetivo avaliar os parâmetros preconizados pela Resolução COFEN n0293/04, enquanto referência para o dimensionamento de pessoal de Enfermagem em e Terapia Intensiva Adulto (UTIA). A pesquisa foi desenvolvida em seis hospitais da cidade de São Paulo. Os quantitativos médios diários de profissionais, necessários para o atendimento dos pacientes, foram calculados conforme parâmetros preconizados pelo COFEN. Os resultados obtidos foram comparados ao quantitativo diário de pessoal existente nessas unidades. Observou-se que as proporções recomendadas pelo COFEN, para a categoria enfermeiro, são superiores às utilizadas pelos hospitais estudados, configurando-se em um desafio para a Enfermagem brasileira. Constatou-se que os valores referentes aos tempos médios de assistência são adequados e constituem importante referencial para o dimensionamento do quantitativo mínimo de profissionais, nas UTIAs. Com este estudo, evidenciaram-se contribuições para a validação dos parâmetros indicados pela Resolução COFEN n²93/04, para o dimensionamento de pessoal de Enfermagem em UTIA.

Descritores: Administração de Pessoal; Recursos Humanos de Enfermagem no Hospital; Carga de Trabalho.

\section{Tiempo de asistencia de enfermería en la Unidad de Cuidados Intensivos: evaluación de los parámetros propuestos por la Resolución COFEN n' 293/04}

Este estudio tuvo como objetivo evaluar los parámetros establecidos por la Resolución COFEN 293/04, referencia para dimensionamiento de personal de enfermería en unidades de cuidados intensivos adultos (UCIA). La investigación se realizó en seis hospitales de la ciudad de São Paulo. La cantidad media diaria de profesionales necesarios para la asistencia al paciente se calculó de acuerdo a los parámetros establecidos por COFEN. Los resultados se compararon al cuantitativo diario de personal existente en estas Unidades. Se observó que las proporciones recomendadas por COFEN, categoría enfermera, son superiores a las utilizadas por los hospitales convirtiéndose desafío para la enfermería brasileña. Se encontró que los valores del tiempo medio de asistencia son adecuadas y representan importante referencia para el dimensionamiento del cuantitativo mínimo de profesionales en UCIA. Este estudio evidencia contribuciones para validación de los parámetros especificados en la Resolución COFEN 293/04, para el dimensionamiento del personal de enfermería en UCIA.

Descriptores: Administración de Personal; Personal de Enfermería en Hospital; Carga de Trabajo.

\section{Introduction}

Ongoing transformations in the global political and economic scenario, driven by the growing integration and socialization of communication means and informatics resources, increasingly demand the rapid adaptation from industrial and service sectors, including the health sector, to this new context, where efficiency and quality are fundamental requisites to attend to clients' demands.
In hospital institutions, the Nursing Service plays a fundamental role in the care process. Data from Brazil and the United States show that, depending on the institution, nursing professionals represent more than half of the hospital workforce ${ }^{(1-3)}$, and their remuneration can rise up to $63 \%$ of staff $\operatorname{costs}^{(4)}$. 
Therefore, the heads of these services should prepare themselves to better manage the human resources they are responsible for, particularly focusing on their efficiency, as this is one of the most significant items of hospital efficacy, quality and cost.

In this sense, various studies ${ }^{(5-10)}$ have demonstrated that both the number and qualification of nursing resources in hospitals are associated with care outcomes that, when insufficient or inadequate, can lead to pneumonias, urinary tract infection, increased hospitalization time, shock and high infection levels.

That is the context in which nursing staff dimensioning, as a management instrument for highquality care, needs to be investigated to produce results that permit greater awareness on the meaning of an adequate nursing staff for clients and institutions' needs $^{(11)}$.

Nursing staff dimensioning is defined as a systematic process that suffers quantitative and qualitative staff planning and assessment, necessary to provide care, according to the singularity of health services, so as to guarantee users and workers' safety ${ }^{(12)}$.

In Resolution 293/04(13), the Federal Nursing Council (COFEN) set parameters to dimension the minimum number of nursing staff for care coverage at health institutions, based on characteristics related to the organization, nursing service and clients. To get to know the client profile at each hospitalization unit, in the Resolution ${ }^{(13)}$, four out of five care categories in the Patient Classification System (PCS) by Fugulin et al. ${ }^{(14)}$ were attested and, for each category, the care time was proposed in hours per patient/24 hours, as well as the percentage distribution of the professional nursing categories.

In Article $4^{\text {th }}$ of this Resolution ${ }^{(13)}$, it was established that:

"For calculation purposes, the following should be considered as Nursing hours, per bed, per 24 hours:

- 3.8 hours of Nursing, per client, in minimal care or self-care;

- 5.6 hours of Nursing, per client, in intermediary care;

- 9.4 hours of Nursing, per client, in semi-intensive care;

- 17.9 hours of Nursing, per client, in intensive care"(13).

As regards chronic patients' care needs, in paragraph $9^{\text {th }}$ of Resolution No. 293/04(13), the following was established:
" $\S 9^{\text {th }}$ - For chronic clients over 60 years of age, without a companion, classified in the PCS as intermediary or semi-intensive care demand, 0.5 should be added to the Nursing hours specified in Article $4^{\text {th }}$ (13)

For the percentage distribution of all nursing staff, recommended in the same Resolution, in Article $5^{\text {th }}$ :

"The percentage distribution of all nursing professionals should comply with the following proportions and the PCS:

1. For minimum and intermediary care: between 33 and $37 \%$ are Nurses (minimum six) and the remainder Nursing Auxiliaries and/or Technicians;

2. For semi-intensive care: between 42 and $46 \%$ are Nurses and the remainder Nursing Auxiliaries and/or Technicians;

3. For intensive care: between 52 and 56\% are Nurses and the remainder Nursing Auxiliaries and/or Technicians.

Single paragraph - The distribution per professional category should be in accordance with the most prevalent patient group"(13).

In view of the established parameters and the importance of analyzing the applicability of COFEN Resolution No. 293/04(13), as a reference for nursing staff dimensioning at hospital institutions, the aim of this study is to assess the parameters recommended in COFEN Resolution No. 293/04(13) as one of the official references for nursing staff dimensioning at adult intensive care units (AICU).

\section{Methods}

An exploratory and descriptive, prospective quantitative field research was developed at the AICU of six public and private hospitals located in São Paulo City, which complied with the following inclusion criteria: having a permanent education service or developing nursing staff training and development programs; having nurses working on all shifts and developing care planning through the nursing process.

These hospitals were identified with the letters of the alphabet. Letters A and $B$ were distributed between the public hospitals and letters C, D, E and F among the private ones. Thus, the institutions were cited using the letter $\mathrm{H}$ (Hospital), followed by the letter corresponding to each institution. Figure 1 summarizes these hospitals' characteristics. 


\begin{tabular}{|c|c|c|c|c|c|}
\hline Hospital institution & Characteristic & No. of beds & Complexity & No. of ICU beds & Semi-intensive beds \\
\hline $\mathrm{HA}$ & General / public / teaching & 236 & Medium & 12 & Yes \\
\hline $\mathrm{HB}$ & General / public / teaching & 934 & High & 39 & No \\
\hline $\mathrm{HC}$ & General / private & 511 & High & 36 & Yes \\
\hline $\mathrm{HD}$ & General / private & 161 & Medium & 23 & No \\
\hline $\mathrm{HE}$ & General / private & 175 & High & 15 & Yes \\
\hline $\mathrm{HF}$ & General / private & 150 & High & 28 & No \\
\hline
\end{tabular}

Figure 1 - Characterization of Hospitals and Intensive Care Units of HA, HB, HC, HD, HE and HF. São Paulo, SP, Brazil, 2007

To achieve the proposed study aim, the nursing staff projection phases needed for care delivery to AICU patients and the care time parameters recommended in COFEN Resolution No. 293/04(13) were followed.

To obtain data on the mean daily number of patients attended at the AICU, according to the care categories recommended in COFEN Resolution No. 293/04(13), patients were classified during 20 typical days, that is, days when the unit was not exposed to any type of event that could interfere in the number of patients attended(12), using the Patient Classification Instrument (PCI) by Fugulin (15-16). To guarantee uniform data collection, all patients hospitalized at these Units were classified during the morning shift by nurses trained to perform this procedure. The information was stored in an electronic worksheet that permitted calculating the mean number of hospitalized patients, classified per care category. A statistical method was applied to calculate the classification sample, using a $95 \%$ confidence interval.

Due to random variations in the number of patients hospitalized at the AICU, besides the mean daily number of patients, the standard deviation and median of the samples were calculated. With a view to eliminating possible distortions in staff number forecasts, we decided to exclude data about those days when patient number were superior or inferior to daily means by two standard deviations.

As COFEN Resolution No. 293/04(13) did not assert the care category high dependence of nursing, which is part of Fugulin's patient classification instrument(15-16), for calculation purposes, patients in this care category were considered part of the semi-intensive care category, as the nursing care dependence profile in these two categories is similar(15).

Data regarding the patients' age and presence of a companion were also collected, due to paragraph $9^{\text {th }}$ of Resolution No. 293/04(13), which establishes that, for chronic patients aged over 60 years, without a companion, with intermediary or semi-intensive care demands, 0.5 should be added to the number of care hours. Therefore, 0.5 nursing care hours were added for patients who fit into this profile.

At the six AICU under analysis, the nursing team's work journey amounted to six hours.

After surveying the variables described above, the equation was applied to determine the daily number of nursing staff members needed to attend patients, indicated in COFEN Resolution No. 293/04(13):

$\mathrm{QP}=\frac{[(3.8 \times \mathrm{PCM})+(5.6 \times \mathrm{PCI})+(9.4 \times \mathrm{PCSI})+(17.9 \times \mathrm{PCIt})]}{\mathrm{JDT}}$

Where:

$\mathrm{QP}=$ daily quantity of nursing professionals;

$\mathrm{PCM}=$ mean daily quantity of patients classified in the minimal care category;

$\mathrm{PCI}=$ mean daily quantity of patients classified in the intermediary care category;

PCSI = mean daily quantity of patients classified in the semi-intensive care category;

PCIt = mean daily quantity of patients classified in the intensive care category;

JDT = work journey of nursing team professionals;

$3.8 ; 5.6 ; 9.4 ; 17.9=$ mean hours of nursing care, recommended in COFEN Resolution No. 293/04(16) for minimal, intermediary, semi-intensive and intensive care categories, respectively.

After obtaining daily staff numbers, they were distributed among the professional categories comprising the nursing team, according to the proportions indicated in Article $5^{\text {th }}$ of COFEN Resolution No. 293/04(13), also observing the most prevalent care category at each Unit. As the percentages of nursing professionals determined in the COFEN Resolution ${ }^{(13)}$ vary according to pre-established intervals, as a criterion for this phase of the dimensioning method, in this research, the mean value of the proportions COFEN indicates was adopted.

The quantitative and qualitative daily means for nursing professionals projected for the AICU, according to the parameters of COFEN Resolution No. 293/04(13) 
was compared with the quantitative and qualitative daily means of nursing professionals, according to professional category (nurses and nursing auxiliaries/ technicians), existing in each work shift, at each Unit. This information was obtained from the daily professional distribution scales existing at the Units, and registered in an appropriate instrument.

Data were collected between February $26^{\text {th }}$ and March $17^{\text {th }} 2007$ and stored in a database constructed for the research.

The results were presented through graphs and tables, with central trend and variability measures. To compare mean staff numbers according to COFEN
Resolution ${ }^{(13)}$ parameters with existing means at the Hospitalization Units under analysis, the t-test was used, with significance set at 5\%.

Approval for the project was obtained from the Research Ethics Committees at HA, HC and HF; from the Ethics Committee for Research Project Analysis of HB's Clinical Board, and from HD and HE's Clinical Board.

\section{Results}

The classification results for patients hospitalized at the AICU under analysis are demonstrated in Table 1.

Table 1 - Patient distribution at hospitals' AICU according to care category. São Paulo, SP, Brazil, 2007

\begin{tabular}{|c|c|c|c|c|c|c|c|c|c|c|c|}
\hline \multirow{3}{*}{ Hospital } & \multicolumn{11}{|c|}{ Care Category } \\
\hline & \multicolumn{2}{|c|}{ Intensive } & \multicolumn{2}{|c|}{ Semi-intensive } & \multicolumn{2}{|c|}{ High dependence } & \multicolumn{2}{|c|}{ Intermediary } & \multicolumn{2}{|c|}{ Minimal } & \multirow{2}{*}{ Total } \\
\hline & $\mathbf{N}$ & $\%$ & $\mathbf{N}$ & $\%$ & $\mathbf{N}$ & $\%$ & $\mathbf{N}$ & $\%$ & $\mathbf{N}$ & $\%$ & \\
\hline $\mathrm{HA}$ & 140 & 70 & 45 & 23 & 14 & 7 & 1 & 1 & - & - & 200 \\
\hline $\mathrm{HB}$ & 436 & 67 & 84 & 13 & 135 & 21 & - & - & - & - & 655 \\
\hline $\mathrm{HC}$ & 291 & 77 & 21 & 6 & 46 & 12 & 18 & 5 & 2 & 0,01 & 378 \\
\hline $\mathrm{HD}$ & 223 & 64 & 53 & 15 & 65 & 19 & 7 & 2 & - & - & 348 \\
\hline $\mathrm{HE}$ & 120 & 60 & 55 & 28 & 25 & 13 & - & - & - & - & 200 \\
\hline $\mathrm{HF}$ & 142 & 34 & 135 & 32 & 132 & 31 & 13 & 3 & - & - & 422 \\
\hline
\end{tabular}

Table 2 shows the existing mean daily number of professionals at the AICU of the study hospitals, as well as their percentage distribution among the professional nursing categories at each AICU.

Table 2 - Distribution of nursing professional according to professional category at the hospitals' AICU. São Paulo, SP, Brazil, 2007

\begin{tabular}{|c|c|c|c|c|c|c|c|c|c|c|c|c|c|c|c|c|c|c|}
\hline \multirow{2}{*}{ Hospital } & \multicolumn{6}{|c|}{ Nurses/shift } & \multicolumn{6}{|c|}{ Technicians and Auxiliaries/shift } & \multicolumn{6}{|c|}{ Team/shift } \\
\hline & M & $\mathbf{T}$ & N1 & N2 & Total & $\%$ & M & $\mathbf{T}$ & N1 & N2 & Total & $\%$ & M & $\mathbf{T}$ & N1 & N2 & Total & $\%$ \\
\hline HA & 3.0 & 3.0 & 2.0 & 2.0 & 10.0 & 31.3 & 6.0 & 6.0 & 5.0 & 5.0 & 22.0 & 68.8 & 9.0 & 9.0 & 7.0 & 7.0 & 32.0 & 100.0 \\
\hline HB & 10.0 & 8.0 & 5.0 & 5.0 & 28.0 & 31.1 & 16.0 & 16.0 & 15.0 & 15.0 & 62.0 & 68.9 & 26.0 & 24.0 & 20.0 & 20.0 & 90.0 & 100.0 \\
\hline $\mathrm{HC}$ & 7.0 & 7.0 & 6.0 & 6.0 & 26.0 & 31.7 & 14.0 & 14.0 & 14.0 & 14.0 & 56.0 & 68.3 & 21.0 & 21.0 & 20.0 & 20.0 & 82.0 & 100.0 \\
\hline HD & 2.0 & 2.0 & 1.0 & 1.0 & 6.0 & 15.8 & 8.0 & 8.0 & 8.0 & 8.0 & 32.0 & 84.2 & 10.0 & 10.0 & 9.0 & 9.0 & 38.0 & 100.0 \\
\hline $\mathrm{HE}$ & 1.0 & 1.0 & 1.0 & 1.0 & 4.0 & 13.3 & 7.0 & 7.0 & 6.0 & 6.0 & 26.0 & 86.7 & 8.0 & 8.0 & 7.0 & 7.0 & 30.0 & 100.0 \\
\hline HF & 4.0 & 3.0 & 2.0 & 2.0 & 11.0 & 18.6 & 12 & 12.0 & 12.0 & 12.0 & 48.0 & 81.4 & 16.0 & 15.0 & 14.0 & 14.0 & 59.0 & 100.0 \\
\hline
\end{tabular}

$M=$ work shift from 7:00 till 13:00; $T=$ work shift from 13:00 till 19:00; N1= work shift from 19:00 till 7:00 (shift 12 hours for 36 hours); N2= work shift from 19:00 till 7:00 (shift 12 hours for 36 hours).

The comparison between the mean daily number of nursing professional projected for the AICU under analysis according to COFEN Resolution No. 293/04(13) and the existing staff numbers is shown in Table 3. 
Table 3 - comparison between the mean daily number of nursing professionals projected for the Intensive Care Units at HA, HB, HC, HD, HE and HG, according to the parameters of COFEN Resolution No. 293/04(13), in relation to existing staff members at these Units. São Paulo, Brazil, 2007

\begin{tabular}{|c|c|c|c|c|c|c|c|}
\hline \multirow{2}{*}{ Institution } & \multirow{2}{*}{ Projected staff } & \multirow{2}{*}{ se } & \multirow{2}{*}{$\mathbf{t}_{95 \%}$} & \multicolumn{2}{|c|}{ Calculated $95 \%$ confidence interval } & \multirow{2}{*}{ Existing staff } & \multirow{2}{*}{$p$-value } \\
\hline & & & & Li & Ls & & \\
\hline $\mathrm{HA}$ & 25.7 & 4.64 & 2.093 & 23.5 & 27.9 & 32 & $<0.001$ \\
\hline $\mathrm{HB}$ & 82.5 & 2.88 & 2.093 & 81.3 & 83.9 & 90 & $<0.001$ \\
\hline $\mathrm{HC}$ & 83.1 & 8.55 & 2.201 & 77.7 & 88.5 & 82 & 0.66 \\
\hline $\mathrm{HD}$ & 41.0 & 4.03 & 2.086 & 39.2 & 42.8 & 38 & 0.0028 \\
\hline $\mathrm{HE}$ & 24.5 & 7.28 & 2.093 & 21.1 & 27.9 & 30 & 0.0032 \\
\hline $\mathrm{HF}$ & 45.7 & 6.86 & 2.101 & 42.4 & 49.0 & 59 & $<0.001$ \\
\hline
\end{tabular}

The statistical comparison between the means, lower and upper limits of the projected nursing staff for the six AICU under analysis and existing staff numbers evidenced a statistically significant difference between projections and existing staff for five Units.
The comparison between staff numbers by category, obtained according to the percentage distribution recommended in COFEN Resolution No. 293/04 ${ }^{(13)}$ and existing staff numbers at the AICU under analysis is displayed in Figure 2.

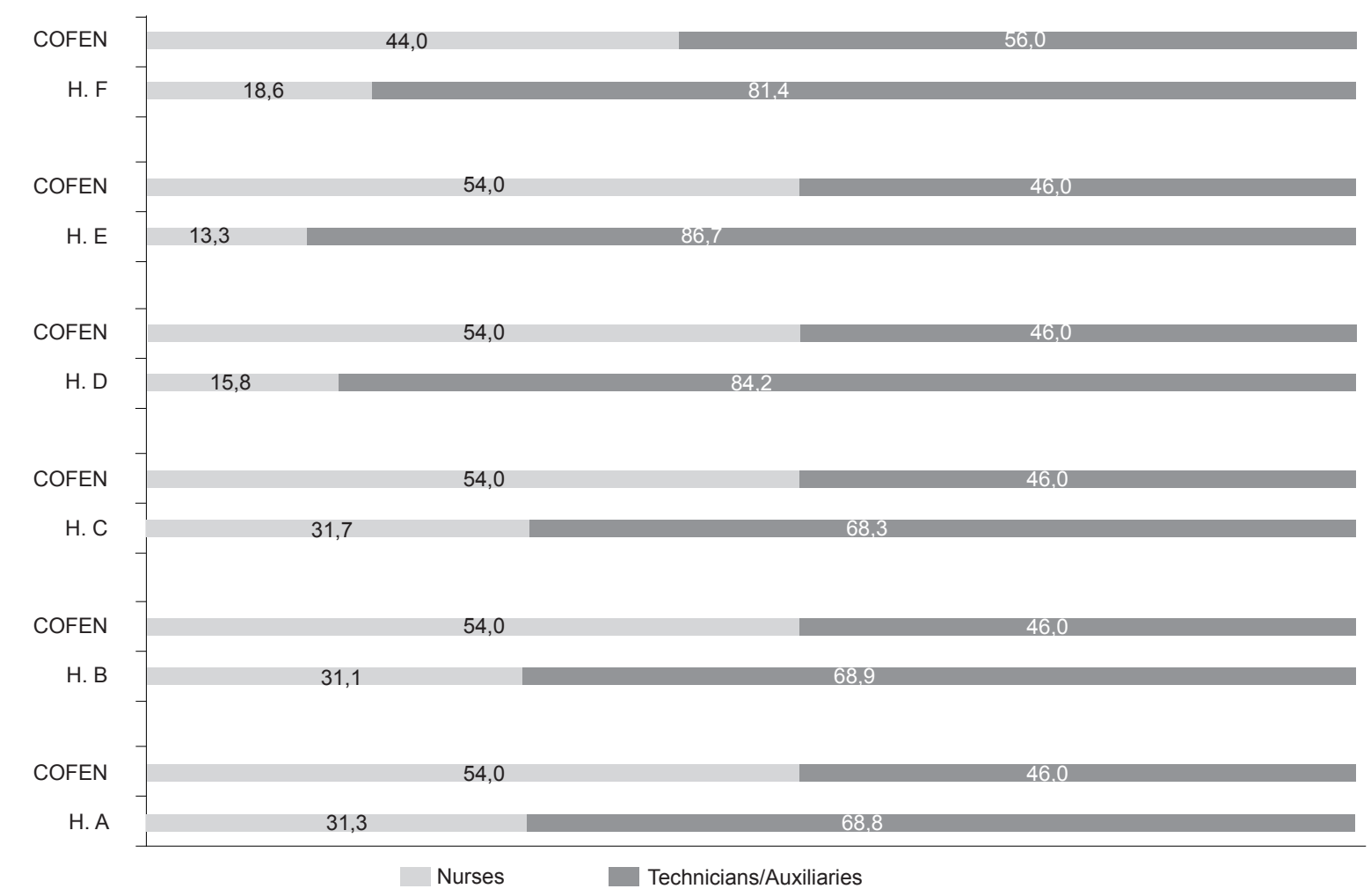

Figure 2 - Comparison between percentage distribution of projected mean daily nursing staff numbers according to the parameters of COFEN Resolution No. 293/04(13) and the percentage distribution found at the Intensive Care Units of HA, HB, HC, HD, HE and HF. São Paulo, Brazil, 2007

According to Figure 2, at all AICU under analysis, the proportion of nurses was lower than that established in COFEN Resolution No. 293/04(13), so that the percentage of nursing technicians/auxiliaries exceeded the indicated proportion.

\section{Discussion}

The obtained results for the classification of patients hospitalized at each AICU demonstrates that, although these are Intensive Care Units, all units also 
attend patients classified in the semi-intensive and high nursing dependence care categories. This finding may be related to the lack of specific units for care to these patients, like semi-intensive care units, which were not found in $\mathrm{HB}, \mathrm{HD}$ and $\mathrm{HF}$, or to factors related to the medical team's work dynamics.

Highly dependent patients' characteristics can justify their stay, as their care profile is similar to that of semi-intensive care patients, mainly regarding nursing care needs. For the same reasons, they would remain hospitalized at these units.

The presence of intermediary care patients, on the other hand, observed at most institutions, and of a minimal care patient, identified at only one institution, may be due to different reasons, including the fact that these patients were awaiting transfers to others Units at the moment of the classification or the medical team's option to keep them at the AICU.

The presence of patients of lower care complexity at the AICU decreases the nursing team's workload. Thus, if they have been planned to attend intensive care patients only and given the direct consequences for the cost of care delivery, bed management at these institutions can be assessed to optimize these resources.

The comparison between the projected mean number of professionals for the AICU and existing staff numbers showed significantly higher staff numbers at the Intensive Care Units of $\mathrm{HA}, \mathrm{HB}, \mathrm{HE}$ and $\mathrm{HF}$ than the upper limit of the confidence interval, while the ICU at HD displayed a statistically lower number of professionals than the lower limit of the confidence interval calculated at $95 \%$. Existing staff numbers at the ICU of $\mathrm{HC}$ were statistically similar to projected numbers, according to the parameters recommended in COFEN Resolution No. $293 / 04^{(13)}$, staying within the upper and lower limits of the confidence interval.

When existing staff numbers are higher than the upper limit of the confidence interval for the projected staff, one may consider that, on some days during the study period, available staff numbers exceeded the care needs of hospitalized patients. Independently of the reason characterizing this situation, the existence of a larger staff confirms the mean care hours recommended in COFEN Resolution No. 293/04(13), as these hours represent a minimum reference framework for staff dimensioning at health institutions.

The units analyzed did not confirm the proportions of professionals COFEN indicated for nursing staff composition at hospitalization units.

The results appointed in this research regarding the percentage distribution of mean staff numbers among the nursing team categories support other researchers ${ }^{\prime(15,17)}$ findings, who previously demonstrated that the proportion of care hours attributed to nurses at Brazilian health institutions is lower than that attributed to nursing auxiliaries and technicians, and that they remain very distant from current COFEN recommendations.

Studies available in international literature correlated the number of nursing hours with the quality of care delivery, concluding that the larger number of care hours nurses deliver is associated with lower mortality and adverse event rates, as well as with the drop in mortality rates deriving from these events ${ }^{(18-21)}$.

From a financial viewpoint, a study(2) concluded that, when the number of nurses in hospitals increased, this also meant a significant rise in operating costs, but without a decrease in profits. On the other hand, in hospitals where the number of technical professionals was higher when compared to nurses, high operating costs were found, accompanied by smaller profits.

The analysis of these studies evidences that improving the percentage distribution of the care hours attributed to nurses still represents a challenge for Brazilian nursing.

As a theme for future research, we find it relevant to assess the indications formulated by the Board of Directors of the National Health Surveillance Agency (ANVISA) which, through RDC No. 07(22), determines the minimal requisites for ICU functioning, including the quantitative and qualitative composition of the nursing team. This assessment can offer further support for nurses, responsible for compliance with the laws that rule on professional practice, to negotiate on the nursing staff with hospital administrators.

\section{Conclusion}

This study permitted the assessment of the parameters recommended in COFEN Resolution No. $293 / 04$, as one of the official references for nursing staff dimensioning at AICU.

Concerning the distribution of the workload among the professional categories in the nursing team, the proportion of hours attributed to nurses is lower than that of nursing technicians and auxiliaries and remains distant from COFEN recommendations, which represents a challenge for Brazilian nursing.

The mean care times COFEN recommends are adequate though, constituting an important reference framework for dimensioning the minimum number of nursing professionals at AICU. 
We believe that this study contributed to the validation of the parameters indicated in COFEN Resolution No. 293/04 for nursing staff dimensioning at AICU.

\section{References}

1. American Hospital Association. The hospital worforce shortage: immediate and future. Trendwatch. $2001 ; 3(2): 1-8$.

2. McCue B, Mark BA, Harless DW. Nurse staffing, quality and financial performance. J Health Care Finance. 2003;29(4):54-76.

3. Castilho V, Fugulin FMT, Gaidzinski RR. Gerenciamento de custos nos serviços de enfermagem. In: Kurcgant $P$, coordenador. Gerenciamento em enfermagem. 2.ed. Rio de Janeiro: Guanabara Koogan; 2010. p. 169-80.

4. American Hospital Association [Internet]. Cost of caring: key drivers of growth in spending on hospital care. 2003. [acesso $17 \mathrm{fev} 2011$ ]

Disponível em: http://www.aha.org/aha/content/2003/ pdf/PwCcostsReport.pdf

5. Needleman J, Buerhaus PI, Stewart M, Zeleninsky K, Mattke $S$. Nurse staffing in hospitals: is there a business case for quality? Health Aff. 2006;25(1):204-11.

6. Kane RL, Shamliyan TA, Mueller C, Duval S, Wilt TJ. The association of registered nurse staffing levels and patient outcomes: systematic review and meta-analysis. Med Care. 2007;45(12):1195-204.

7. Hugonnet S, Chevrolet JC, Pittet D. The effect of workload on infection risk in critically ill patients. Crit Care Med. 2007;35:76-81.

8. Stone PW, Mooney-Kane C, Larson EL, Horan T, Glance LG, T. Horan, et al. Nursing working conditions and patient safety outcomes. Med Care. 2007;45(6):571-8.

9. Hugonnet S, Uckay I, Pittet D. Staffing level:

a determinant of late-onset ventilator-associated pneumonia. Crit Care. 2007;11:R80.

10. Penoyer DA. Nurse staffing and patient outcomes in critical care: a concise review. Crit Care Med. 2010;38(7):1521-8.

11. Gaidzinski RR. Dimensionamento de pessoal de enfermagem em instituições hospitalares [tese livredocência]. São Paulo (SP): Escola de Enfermagem da Universidade de São Paulo; 1998.

12. Fugulin FMT, Gaidzinski RR, Castilho V. Dimensionamento de pessoal de enfermagem em instituições de saúde. In: Kurcgant $P$, coordenador. Gerenciamento em enfermagem. 2.ed. Rio de Janeiro: Guanabara Koogan; 2010. p. 121-35.
13. Resolução no 293/04. Fixa e estabelece parâmetros para dimensionamento do quadro de profissionais de enfermagem nas instituições de saúde. Conselho Regional de Enfermagem. [Internet]. 2004. [acesso 14 nov 2004]. Disponível em: http://www.corensp.org.br/ resolucao293.htm

14. Fugulin FMT, Silva SHS, Shimizu HE, Campos FPF. Implantação do sistema de classificação de pacientes na unidade de clínica médica do hospital universitário da USP. Rev Med HU-USP. 1994;4(1/2):63-8.

15. Fugulin FMT. Dimensionamento de pessoal de enfermagem: avaliação do quadro de pessoal de enfermagem das unidades de internação de um hospital de ensino [tese de doutorado]. São Paulo (SP): Escola de Enfermagem da Universidade de São Paulo; 2002.

16. Fugulin FMT, Gaidzinski RR, Kurcgant P. Sistema de classificação de pacientes: identificação do perfil assistencial dos pacientes das unidades de internação do HU-USP. Rev. Latino-Am. Enfermagem. 2005;13(1):72-8.

17. Rogenski KE. Tempo de assistência de enfermagem: identificação e análise em instituição hospitalar de ensino [dissertação]. São Paulo (SP): Escola de Enfermagem da Universidade de São Paulo; 2006.

18. McGillis L, Doran D, Pink GH. Nurse staffing models, nursing hours, and patient safety outcomes. JONA. 2004;34(1):41-5.

19. Rafferty AM, Clarke SP, Coles J, Ball J, James P, McKee M, Aiken LH. Outcomes of variation in hospital nurse staffing in England hospitals: cross-sectional analysis of survey data and discharge records. Int J Nurs Stud. 2007;44(2):175-82.

20. Cho SH, Hwang JH, Kim J. Nurse staffing and patient mortality in intensive care units. Nurs Res. 2008;57(5):322-30.

21. Tourongeu $A E$, Doran DM, McGillis Hall $L, O^{\prime}$ Brien Pallas L, Pringe D, Tu JV, Cranley LA. Impact of hospital nursing care on 30-day mortality for acute medical patients. J Adv Nurs. 2007;57(1):32-44.

22. Ministério da Saúde (BR). Agência Nacional de Vigilância Sanitária. Resolução - RDC n. 7, de 24 de fevereiro de 2010. Dispoe sobre os requisitos mínimos para funcionamento de Unidades de Terapia Intensiva e dá outras providências. Diário Oficial da União, Brasília, 25 de fev. de 2010. Seção 1: 48-52.

Received: Feb. $28^{\text {th }} 2011$ Accepted: Sep. $20^{\text {th }} 2011$ 